Article

\title{
Suzuki-Miyaura Reactions of
}

(4-bromophenyl)-4,6-dichloropyrimidine through

Commercially Available Palladium Catalyst:

Synthesis, Optimization and Their Structural Aspects Identification through Computational Studies

\author{
Ayesha Malik ${ }^{1}$, Nasir Rasool ${ }^{1, *}$, Iram Kanwal ${ }^{1}$, Muhammad Ali Hashmi ${ }^{2}$ (D), \\ Ameer Fawad Zahoor ${ }^{1}$, Gulraiz Ahmad ${ }^{1}$, Ataf Ali Altaf ${ }^{3,4} \mathbb{D}$, Syed Adnan Ali Shah ${ }^{5,6} \mathbb{D}^{\text {, }}$ \\ Sadia Sultan ${ }^{5,6}$ and Zainul Amiruddin Zakaria $7,8, *$ (D) \\ 1 Department of Chemistry, Government College University, Faisalabad 38000, Pakistan; \\ ayesha.m726@gmail.com (A.M.); iramchemist117@gmail.com (I.K.); fawad.zahoor@gmail.com (A.F.Z.); \\ gulchemist35@gmail.com (G.A.) \\ 2 Department of Chemistry, University of Education, Attock Campus, Attock 43600, Pakistan; \\ i4hashmi@hotmail.com \\ 3 Centre of Catalysis and Energy Research, Department of Chemistry, University of Okara, \\ Okara 56300, Pakistan; atafali_altaf@yahoo.com \\ 4 Department of Chemistry, University of Okara, Okara 56300, Pakistan \\ 5 Faculty of Pharmacy, Universiti Teknologi MARA Cawangan Selangor Kampus Puncak Alam, Bandar \\ Puncak Alam, Selangor 42300, Malaysia; syedadnan@uitm.edu.my (S.A.A.S.); drsadia@uitm.edu.my (S.S.) \\ 6 Atta-ur-Rahman Institute for Natural Products Discovery (AuRIns), Universiti Teknologi MARA Cawangan \\ Selangor Kampus Puncak Alam, Bandar Puncak Alam, Selangor 42300, Malaysia \\ 7 Department of Biomedical Science, Faculty of Medicine and Health Sciences, Universiti Putra Malaysia, \\ UPM Serdang, Selangor 43400, Malaysia \\ 8 Integrative Pharmacogenomics Institute (iPromise), Universiti Teknologi MARA Cawangan Selangor \\ Kampus Puncak Alam, Bandar Puncak Alam, Selangor 42300, Malaysia \\ * Correspondence: nasirrasool@gcuf.edu.pk (N.R.); zaz@upm.edu.my (Z.A.Z.); Tel.: +92-332-7491790 (N.R.); \\ +60-3-8947-2111 (Z.A.Z.); Fax: +92-41-9201032 (N.R.); +60-3-8943-6178 (Z.A.Z.)
}

Received: 24 August 2020; Accepted: 15 October 2020; Published: 23 October 2020

\begin{abstract}
: 5-(4-bromophenyl)-4,6-dichloropyrimidine was arylated with several aryl/heteroaryl boronic acids via the Suzuki cross-coupling reaction by using $\operatorname{Pd}(0)$ catalyst to yield novel pyrimidine analogs (3a-h). It was optimized so that good yields were obtained when $5 \mathrm{~mol} \% \operatorname{Pd}(\mathrm{PPh} 3) 4$ was used along with $\mathrm{K}_{3} \mathrm{PO}_{4}$ and 1,4-Dioxane. Electron-rich boronic acids were succeeded to produce good yields of products. Density functional theory (DFT) calculations were also applied on these new compounds to analyze their reactivity descriptors and electronic and structural relationship. According to DFT studies, compound $\mathbf{3 f}$ is the most reactive one, while $\mathbf{3 g}$ is the most stable one. As per DFT studies, the hyperpolarizability $(\beta)$ values of these compounds do not show them as very good non-linear optical (NLO) materials. Compound $3 \mathrm{f}$ has the highest $\beta$ value among all the compounds under study but still it is not high enough to render it a potent NLO material.
\end{abstract}

Keywords: Suzuki-Miyaura; Pd catalyst; DFT; reactivity descriptors; FMO

\section{Introduction}

Pyrimidines are two nitrogen containing heterocycles and, being the basic moieties in DNA and RNA, indicate their importance in a large number of biological activities [1]. It is found that 
pyrimidine and all the molecules containing a pyrimidine nucleus possess a wide spectrum of biological activities including anticancer [2,3], antioxidant [4], antimicrobial [5], antiviral [6], anti-inflammatory [7], analgesic [8], antimalarial [9], anti-HIV, cardiovascular [10] and anti-diabetic [11] and they also act as calcium channel blockers [12]. Such a widespread use of pyrimidine derivatives in pharmaceutical drugs and agro industries paved the way for us to synthesize various new substituted pyrimidines. During the literature survey, it was analyzed that the direct arylation of halogenated pyrimidines was the focus of many chemists, which gives excellent yield $[13,14]$. The production of mono-, di- and tri-substituted pyrimidines was the subject of study for many researchers by examining the halogen group to be replaced and the most reactive site of pyrimidine, and regioselectivity was also examined [13,15]. Meanwhile, the arylation of the pyrimidine-substituted bromo-phenyl ring has not been reported so far.

Many different methodologies are available for arylation [16,17], while the Suzuki coupling method is the most versatile and frequently used method $[18,19]$, due it its tolerance for moisture by various boronic acids and also by its ability to cover a large number of functional groups $[20,21]$. Moreover, a number of different catalysts were reported for arylation [22,23]. From some years ago, the direct arylation of hetero-aromatics with palladium catalyst has become an efficient method for the production of arylated hetero-aromatics [24,25]. By keeping in view the importance of pyrimidines and palladium-catalyzed arylation [26], the present work focuses on synthesizing new analogs of phenyl-substituted pyrimidines through a palladium-catalyzed Suzuki cross-coupling reaction with special emphasis on the effect of halo-substituted boronic acid, solvent and base on the yield. With this context, pyrimidines substituted to phenyl are a good choice for Suzuki coupling reactions. Density functional theory (DFT) calculations have been executed on the newly arylated products to know about their electronic and structural properties. An analysis of frontier orbitals and other reactivity descriptors including $A, I, \mu, \eta$ and $\omega$ was performed. Hyperpolarizability $(\beta)$ values of the compounds have been calculated to check the compounds for their electron push and pull mechanism through the intramolecular charge transfer which can predict them to be good non-linear optical (NLO) materials.

\section{Materials and Methods}

\subsection{Chemicals Used for Coupling of 5-(4-bromophenyl)-4,6-dichloropyrimidine with Boronic Acid}

Analytical-grade reagents were used in all experiments and purchased from Sigma Aldrich Alfa and Aesar Chemical Company. All reactions were performed in inert atmosphere by using a Schlenk flask. The reactions were checked with TLC by using silica gel plates. Visualization was accomplished by $254 \mathrm{~nm}$ UV light.

\subsection{Procedure for Synthesis of 5-([17]-4-yl)-4,6-dichloropyrimidine}

$\mathrm{Pd}\left(\mathrm{PPh}_{3}\right)_{4}(5 \mathrm{~mol} \%)$ catalyst and 5-(4-bromophenyl)-4,6-dichloropyrimidine $(0.986 \mathrm{mmoL})$ were added in the Schlenk flask containing $6 \mathrm{~mL}$ of solvent, and the mixture was stirred under an inert atmosphere for $30 \mathrm{~min}$ at room temperature. After half an hour, aryl/het-aryl boronic acids $(1.08 \mathrm{mmoL})$, base $(1.972 \mathrm{mmoL})$ and distilled. $\mathrm{H}_{2} \mathrm{O}(1.5 \mathrm{~mL})$ were added in the reaction mixture and the mixture continued to reflux at $70-80^{\circ} \mathrm{C}$ for $18-22 \mathrm{~h}$. After completion, the reaction mixture was allowed to cool to room temperature and then ethyl acetate was added in the reaction mixture. The organic fraction was separated, dried with magnesium sulphate $\left(\mathrm{MgSO}_{4}\right)$ and solvent was removed by a rotary evaporator. The crude product was refined by a flash column using n-hexane and ethyl acetate. Final products were confirmed via $1 \mathrm{H}-\mathrm{NMR}, 13 \mathrm{C}-\mathrm{NMR}$, mass spectrometry and elemental analysis $[27,28]$.

\subsection{Computational Methods}

For the prediction of different electronic characteristics of compounds, computational study has been proved a powerful tool and Gaussian 09 software was used to compute these properties [29]. 
A hybrid density functional (PBE0) [30] with 25\% Hartree Fock exchange was used [31]. Triple $\zeta$ basis set Def2-TZVP [32] was used with empirical dispersion correction (D3) by Grimme [33-35]. The solvent effect was also induced through the polarizable continuum model (PCM) [36-42] with the Solvent Model Density (SMD) parameter set by Truhlar [43]. In all computations, water was used as solvent. To verify the structures as true minima, frequency calculations were measured on optimized geometries. No imaginary frequencies confirmed the structures to be true minima. Structural visualizations were done through CYLview and GaussView 5.0.9 [44] software.

\section{Results}

\subsection{Chemistry}

The general pathway for the preparation of a series of 5-([1,1'-biphenyl]-4-yl)-4,6-dichloro pyrimidine is shown in Scheme 1, Figure 1.<smiles>Clc1ncnc(Cl)c1-c1ccc(Br)cc1</smiles>

1<smiles>OB(O)c1ccccc1</smiles>

2

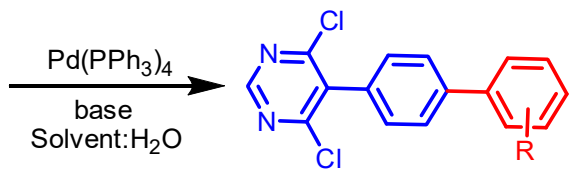

3a-h

Scheme 1. Arylation of pyrimidine derivatives by the Suzuki cross-coupling reaction.<smiles>COc1ccc(-c2ccc(-c3c(Cl)ncnc3Cl)cc2)cc1</smiles><smiles>Clc1ccc(-c2ccc(-c3c(Cl)ncnc3Cl)cc2)cc1</smiles>

3d<smiles>Cc1cc(C)cc(-c2ccc(-c3c(Cl)ncnc3Cl)cc2)c1</smiles>

3b<smiles>Fc1ccc(-c2ccc(-c3c(Cl)ncnc3Cl)cc2)cc1Cl</smiles>

$3 c$<smiles>CC(=O)c1cccc(-c2ccc(-c3c(Cl)ncnc3Cl)cc2)c1</smiles><smiles>CSc1ccc(-c2ccc(-c3c(Cl)ncnc3Cl)cc2)cc1</smiles>

$3 e$<smiles>Clc1ccc(-c2ccc(-c3c(Cl)ncnc3Cl)cc2)cc1Cl</smiles>

Figure 1. Pyrimidine derivatives (3a-3h) obtained by Suzuki cross-coupling using 5-(4-bromophenyl)-4,6-dichloropyrimidine as the coupling component.

The Suzuki-Miyaura reaction of 5-(4-bromophenyl)-4,6-dichloropyrimidine (1) with various aryl-boronic acids (1.1 equivalents) afforded 5-([1,1'-biphenyl]-4-yl)-4,6-dichloropyrimidines (Scheme 1, Table 1). The influence of different bases and solvents was examined for these couplings (Table 1). All the reactions were done by using $\mathrm{Pd}\left(\mathrm{PPh}_{3}\right)_{4}$ at $70-80{ }^{\circ} \mathrm{C}$ and under inert atmosphere. However, during this research work, 3a was synthesized by taking the $\mathrm{K}_{3} \mathrm{PO}_{4}$ as the base but three different solvents, dry toluene, acetonitrile and 1,4-dioxane, were examined. A moderate to good $(40 \%, 36 \%$, $60 \%$ ) yield was gained (Table 1). Similarly, $3 \mathrm{~d}$ was synthesized by keeping the base the same but two different solvents, 1,4-dioxane and DMF, were tested for getting a better yield. A 15\% yield was produced in 1,4-dioxane, while $20 \%$ yield was gained when DMF was used (Table 1). It was noticed that $\mathbf{3 d}$ was gained in better yield in DMF than 1,4-dioxane but DMF was not selected for further reactions due to its difficulty in removal at the end of the reaction. However, $\mathbf{3} \mathbf{b}$ was synthesized 
by taking dry toluene as solvent, whereas two different bases $\left(\mathrm{K}_{3} \mathrm{PO}_{4}\right.$ and $\left.\mathrm{Cs}_{2} \mathrm{CO}_{3}\right)$ were examined. A good $(70 \%, 80 \%)$ yield was gained (Table 1$)$. Moreover, we tried to synthesize $3 \mathrm{c}$ by using two different solvents (dry toluene and 1,4-dioxane) and two different bases $\left(\mathrm{K}_{3} \mathrm{PO}_{4}\right.$ and $\left.\mathrm{Cs}_{2} \mathrm{CO}_{3}\right)$. It was noted that the required product was not produced when electron-withdrawing aryl boronic acids were used with different bases and solvents due to the large number of side products obtained in both cases (Table 1).

Table 1. Derivatives of 5-([1,1'-biphenyl]-4-yl)-4,6-dichloropyrimidine with percentage yields.

\begin{tabular}{|c|c|c|c|c|}
\hline Compounds & Boronic Acid & Solvent: $\mathrm{H}_{2} \mathrm{O}$ & Base & Percentage Yield ${ }^{[a]}$ \\
\hline \multirow{3}{*}{$3 a$} & \multirow{3}{*}{ 4-methoxy Phenyl } & Dry Toluene & \multirow{3}{*}{$\mathrm{K}_{3} \mathrm{PO}_{4}$} & $40 \%$ \\
\hline & & Acetonitrile & & $36 \%$ \\
\hline & & 1,4-dioxane & & $60 \%$ \\
\hline \multirow{2}{*}{$3 b$} & \multirow{2}{*}{ 3,5-Dimethyl Phenyl } & \multirow{2}{*}{ Dry Toluene } & $\mathrm{K}_{3} \mathrm{PO}_{4}$ & $70 \%$ \\
\hline & & & $\mathrm{Cs}_{2} \mathrm{CO}_{3}$ & $80 \%$ \\
\hline \multirow{2}{*}{$3 c$} & \multirow{2}{*}{ 3-Chloro-4-fluoro Phenyl } & Dry Toluene & $\mathrm{Cs}_{2} \mathrm{CO}_{3}$ & Not formed \\
\hline & & 1,4-dioxane & $\mathrm{K}_{3} \mathrm{PO}_{4}$ & Not formed \\
\hline \multirow{2}{*}{$3 d$} & \multirow{2}{*}{ 4-chloro Phenyl } & 1,4-Dioxane & \multirow{2}{*}{$\mathrm{K}_{3} \mathrm{PO}_{4}$} & $15 \%$ \\
\hline & & DMF & & $20 \%$ \\
\hline $3 e$ & 3-Acetyle Phenyl & 1,4-dioxane & $\mathrm{K}_{3} \mathrm{PO}_{4}$ & $60 \%$ \\
\hline $3 f$ & 4-Methyl Thio Phenyl & 1,4-dioxane & $\mathrm{K}_{3} \mathrm{PO}_{4}$ & $55 \%$ \\
\hline $3 g$ & 3-Chloro Phenyl & 1,4-dioxane & $\mathrm{K}_{3} \mathrm{PO}_{4}$ & $25 \%$ \\
\hline $3 h$ & 3,4-dicholoro Phenyl & 1,4-dioxane & $\mathrm{K}_{3} \mathrm{PO}_{4}$ & $30 \%$ \\
\hline
\end{tabular}

In the present research work, after examining the different bases, solvents and the results of 3a-3d, it was found that $5 \mathrm{~mol} \% \mathrm{Pd}\left(\mathrm{PPh}_{3}\right)_{4}$ produced the best yield along with $\mathrm{K}_{3} \mathrm{PO}_{4}$ and 1,4-Dioxane (Table 1). So, 1,4-dioxane and K3PO4 were selected for all the later reactions. It was also noted that electron-rich boronic acids produced good yields as compared to others. It was noteworthy that $3 \mathbf{e}$ and $\mathbf{3 f}$ were gained in good yield ( $60 \%$ and $55 \%$, respectively) (Table 1$)$. Compounds $\mathbf{3 g}$ and $\mathbf{3 h}$ gave a low yield (25\% and $30 \%$, respectively) (Table 1$)$. During the literature survey, it was noted that a low yield might be attributed to the coordination of the transition metal of catalyst (Pd) with a nitrogen center $[45,46]$ which results in its lower activity. Itoh and Mase had reported the coordination of two nitrogen atoms of pyrimidine with palladium catalyst [47]. The phenomenon of chelation had also been reported for a Schiff base containing nitrogen of pyridine and sulfur of thiophene which are involved in binding with the electrophilic $\mathrm{Pd}$ of $\mathrm{Pd}\left(\mathrm{PPh}_{3}\right)_{4}$ [48] Therefore pyrimidines, having two nitrogen centers, are more liable to such a sort of ligation effect [49]. On the other side, poor yields were obtained with electron-withdrawing substituents, namely boronic acids. Due to the deficiency of electrons on aryl boronic acids, the transmetalation step is slowed [50]. Moreover, the most probable side reaction which lowers the yield is protodeboronation which was reported by Kuivila for the first time in both acidic and basic media and also in the presence of metal ions which leads to the formation of Ar-H linking of aryl boronic acid instead of $\mathrm{Ar}-\mathrm{Ar} / \mathrm{R}$ bond formation with substrates [51-53].

Cox and his coworkers also reported that aryl boronic acids with electron-withdrawing groups like halo groups were very much susceptible to protodeboronation especially at higher levels of $\mathrm{pH}$ [54]. Moreover, it was observed that such substrates which contain an electron-deficient center like nitrogen as pyrimidine have also been shown to exhibit poor yield and slower reaction rates as compared to homo-aryl substrates. So, it was concluded that nitrogen atoms of pyrimidine and electron-withdrawing boronic acids might be affecting the yields of final products $(\mathbf{3 c}, \mathbf{3 d}, \mathbf{3} \mathbf{g}-\mathbf{3 h})$, while use of electron-rich boronic acid and 5-(4-bromophenyl)-4,6-dichloropyrimidine (1) with a 
suitable solvent and catalyst is an ideal condition for the formation of final products (3a-b, $\mathbf{3 e}-\mathbf{f})$, as shown in Table 1.

\subsection{Characterization}

4,6-dichloro-5-(4'-methoxybiphenyl-4-yl)pyrimidine (3a): ${ }^{1} \mathrm{H}-\mathrm{NMR}\left(600 \mathrm{MHz}, \mathrm{CDCl}_{3}\right): \delta 8.96$ (s, 1H), $7.47(\mathrm{~m}, 2 \mathrm{H}), 7.11(\mathrm{~m}, 4 \mathrm{H}), 6.98(\mathrm{~m}, 2 \mathrm{H}), 3.76(\mathrm{~s}, 3 \mathrm{H}) .{ }^{13} \mathrm{C} \mathrm{NMR}\left(150 \mathrm{MHz}, \mathrm{CDCl}_{3}\right): \delta 160,156.6$, 152.8, 140.8, 135.3, 133.1, 132.6, 130.1, 127.2, 126.8, 114.8, 55.8. EI/MS m/z (\%): 332.3 [M+H]+; [M-OCH $\left.{ }_{3}\right]$ $=300.1 ;[\mathrm{M}-2 \mathrm{Cl}]=260.4 ;[\mathrm{M}-2 \mathrm{Cl}, \mathrm{OCH} 3]=229.3$. Analysis calculated for $\mathrm{C}_{17} \mathrm{H}_{12} \mathrm{Cl}_{2} \mathrm{~N}_{2} \mathrm{O}: \mathrm{C}, 61.65 ; \mathrm{H}$, $3.65 ; \mathrm{N}, 8.46$. Found: $\mathrm{C}, 61.60 ; \mathrm{H}, 3.62 ; \mathrm{N}, 8.44 \%$.

4,6-dichloro-5-(3',5'-dimethylbiphenyl-4-yl)pyrimidine (3b): ${ }^{1} \mathrm{H}-\mathrm{NMR}\left(600 \mathrm{MHz}, \mathrm{CDCl}_{3}\right)$ : $\delta$ $9.02(\mathrm{~s}, 1 \mathrm{H}), 7.53(\mathrm{~d}, \mathrm{~J}=2.0 \mathrm{~Hz}, 2 \mathrm{H}), 7.17(\mathrm{~d}, \mathrm{~J}=2.0 \mathrm{~Hz}, 1 \mathrm{H}), 7.01(\mathrm{~m}, 4 \mathrm{H}), 2.38(\mathrm{~s}, 6 \mathrm{H}) .{ }^{13} \mathrm{C}$ NMR $(150$ $\mathrm{MHz}, \mathrm{CDCl} 3): \delta 156.6,152.8,141.2,140.8,138.8,135.3,132.6,129.8,127.2,126.8,125.5,21.9 . \mathrm{EI} / \mathrm{MS} \mathrm{m} / \mathrm{z}$ (\%): $330.3[\mathrm{M}+\mathrm{H}]+;\left[\mathrm{M}-2 \mathrm{CH}_{3}\right]=299.3 ;[\mathrm{M}-2 \mathrm{Cl}]=258.2 ;[\mathrm{M}-2 \mathrm{Cl}, 2 \mathrm{CH} 3]=228.4$. Analysis calculated for $\mathrm{C}_{18} \mathrm{H}_{14} \mathrm{Cl}_{2} \mathrm{~N}_{2}$ : C, 65.67; $\mathrm{H}, 4.29 ; \mathrm{N}$, 8.51 Found: $\mathrm{C}, 65.65 ; \mathrm{H}, 4.30 ; \mathrm{N}, 8.50 \%$.

4,6-dichloro-5-(3' chloro-4' -fluoro-[1, $\mathbf{1}^{\prime}$-biphenyl]-4-yl)pyrimidine (3c): Product not formed.

4,6-dichloro-5-(4'-chlorobiphenyl-4-yl)pyrimidine (3d): 1H-NMR (600 MHz, $\left.\mathrm{CDCl}_{3}\right): \delta 9.05$ (s, 1H), $7.66(\mathrm{~m}, 2 \mathrm{H}), 7.57(\mathrm{~m}, 2 \mathrm{H}), 7.08(\mathrm{~m}, 4 \mathrm{H}) .{ }^{13} \mathrm{C} \mathrm{NMR}\left(150 \mathrm{MHz}, \mathrm{CDCl}_{3}\right): \delta 166.7,165.2,161.5$, 159.43, 157.32, 155.33, 150.67,135.80,134.24, 133.12, 132.14, 131.87, 131.71, 131.55, 131.17, 129.81, 128.55, 123.21,122.92. EI/MS m/z (\%): $336.8[\mathrm{M}+\mathrm{H}]+;[\mathrm{M}-3 \mathrm{Cl}]=229.4$. Analysis calculated for $\mathrm{C}_{16} \mathrm{H}_{9} \mathrm{Cl}_{3} \mathrm{~N}_{2}$ : C, 57.26; H, 2.70; N, 8.35. Found: C, 57.23; H, 2.71; N, 8.33\%

1-(4'-(4,6-dichloropyrimidin-5-yl)biphenyl-4-yl)ethanone (3e): ${ }^{1} \mathrm{H}-\mathrm{NMR}\left(600 \mathrm{MHz}, \mathrm{CDCl}_{3}\right): \delta$ $8.83(\mathrm{~s}, 1 \mathrm{H}), 8.28(\mathrm{~m}, 1 \mathrm{H}), 8.02(\mathrm{~m}, 1 \mathrm{H}), 7.90(\mathrm{~m}, 1 \mathrm{H}), 7.79(\mathrm{~m}, 2 \mathrm{H}), 7.64(\mathrm{~m}, 1 \mathrm{H}), 7.46(\mathrm{~m}, 2 \mathrm{H}), 2.66(\mathrm{~s}, 3 \mathrm{H})$. ${ }^{13} \mathrm{C}$ NMR $\left(150 \mathrm{MHz}, \mathrm{CDCl}_{3}\right): \delta 197.0,161.44,156.84,141.28,140.66,137.77,135.65,132.13,131.74,129.82$, 129.25, 127.82, 127.57, 127.01, 26.79. EI/MS m/z (\%): $344.4[\mathrm{M}+\mathrm{H}]+;[\mathrm{M}-2 \mathrm{Cl}]=272.4 ;\left[\mathrm{M}-\mathrm{COCH}_{3}\right]$ $=300.0 ;\left[\mathrm{M}-2 \mathrm{Cl}, \mathrm{COCH}_{3}\right]=229.1$. Analysis calculated for $\mathrm{C}_{18} \mathrm{H}_{12} \mathrm{Cl}_{2} \mathrm{~N}_{2} \mathrm{O}: \mathrm{C}, 62.99 ; \mathrm{H}, 3.52 ; \mathrm{N}, 8.16$. Found: $\mathrm{C}, 62.95 ; \mathrm{H}, 3.50 ; \mathrm{N}, 8.18 \%$.

4,6-dichloro-5-(4'-(methylthio)biphenyl-4-yl)pyrimidine (3f): ${ }^{1} \mathrm{H}-\mathrm{NMR}\left(600 \mathrm{MHz}, \mathrm{CDCl}_{3}\right): \delta$ $9.09(\mathrm{~s}, 1 \mathrm{H}), 7.73-7.35(\mathrm{~m}, 6 \mathrm{H}), 7.25-7.06(\mathrm{~m}, 2 \mathrm{H}), 2.57(\mathrm{~s}, 3 \mathrm{H}) .{ }^{13} \mathrm{C} \mathrm{NMR}\left(150 \mathrm{MHz}, \mathrm{CDCl}_{3}\right): \delta 156.6$, 152.8, 140.8, 138.3, 137.2, 135.3, 132.6, 128.1, 127.5, 127.2, 126.8, 14.8. EI/MS m/z (\%): 348.5 [M+H]+; $\left[\mathrm{M}-\mathrm{SCH}_{3}\right]=300.3 ;[\mathrm{M}-2 \mathrm{Cl}]=276.5 ;\left[\mathrm{M}-2 \mathrm{Cl}, \mathrm{SCH}_{3}\right]=229.3$. Analysis calculated for $\mathrm{C}_{17} \mathrm{H}_{12} \mathrm{Cl}_{2} \mathrm{~N}_{2} \mathrm{~S}: \mathrm{C}$, $58.80 ; \mathrm{H}, 3.48 ; \mathrm{N}, 8.07$. Found: $\mathrm{C}, 58.82 ; \mathrm{H}, 3.46 ; \mathrm{N}, 8.05$.

4,6-dichloro-5-(3'-chlorobiphenyl-4-yl)pyrimidine (3g): ${ }^{1} \mathrm{H}-\mathrm{NMR}\left(600 \mathrm{MHz}, \mathrm{CDCl}_{3}\right): \delta 9.08$ (s, 1H), $7.91(\mathrm{~m}, 1 \mathrm{H}), 7.54(\mathrm{~m}, 2 \mathrm{H}), 7.36(\mathrm{~m}, 1 \mathrm{H}), 7.07(\mathrm{~m}, 4 \mathrm{H}) .{ }^{13} \mathrm{C}$ NMR $\left(150 \mathrm{MHz}, \mathrm{CDCl}_{3}\right): \delta$ 156.6, 152.8, 141.4 $140.8,135.3,134.8,132.6,129.5,127.8,127.6,127.2,126.8,126.0$. EI/MS m/z (\%): 336.8 [M+H]+; $[\mathrm{M}-3 \mathrm{Cl}]=229.3$. Analysis calculated for $\mathrm{C}_{16} \mathrm{H}_{9} \mathrm{Cl}_{3} \mathrm{~N}_{2}: \mathrm{C}, 57.26 ; \mathrm{H}, 2.70 ; \mathrm{N}, 8.35$. Found: $\mathrm{C}, 57.26 ; \mathrm{H}$, $2.70 ; \mathrm{N}, 8.35 \%$.

4,6-dichloro-5-(3', $\mathbf{4}^{\prime}$-dichlorobiphenyl-4-yl)pyrimidine (3h): ${ }^{1} \mathrm{H}-\mathrm{NMR}\left(600 \mathrm{MHz}, \mathrm{CDCl}_{3}\right): \delta 9.06$ $(\mathrm{s}, 1 \mathrm{H}), 7.84(\mathrm{~m}, 1 \mathrm{H}), 7.65(\mathrm{~m}, 1 \mathrm{H}), 7.42(\mathrm{~d}, \mathrm{~J}=2.5 \mathrm{~Hz}, 1 \mathrm{H}), 6.98(\mathrm{~m}, 4 \mathrm{H}) .{ }^{13} \mathrm{C}$ NMR $\left(150 \mathrm{MHz}, \mathrm{CDCl}_{3}\right): \delta$ 156.6, 152.8, 140.8, 139.5, 135.3, 132.7, 132.5, 132.3, 130.7, 129.2, 127.6, 127.2, 126.8. EI/MS m/z (\%): 370.9 $[\mathrm{M}+\mathrm{H}]+;[\mathrm{M}-4 \mathrm{Cl}]=228.1$. Analysis calculated for chemical formula: $\mathrm{C}_{16} \mathrm{H}_{8} \mathrm{Cl}_{4} \mathrm{~N}_{2}: \mathrm{C}, 51.93 ; \mathrm{H}, 2.18 ; \mathrm{N}$, 7.57. Found: $\mathrm{C}, 51.91 ; \mathrm{H}, 2.15 ; \mathrm{N}, 7.55 \%$.

\subsection{Computational Studies}

All the dichloropyrimidine derivatives (3a-3h, Figure 2) with different substituents have been modeled in 3D and optimized at the PBE0-D3BJ/def2-TZVP/SMD water level of theory. The geometries of the optimized structures were then subjected to the measurement of their vibrational frequencies. This proved them to be true minima on the PES. 


\subsubsection{Frontier Molecular Orbital (FMO) Analysis and Hyperpolarizability}

DFT makes it very easy to calculate the energies of FMOs and this is a necessary part of DFT computation. We can investigate the reactivity of a molecule and other different properties with the help of its FMOs energies [55]. The HOMO-LUMO energy difference of a molecule gives us information about the general reactivity of the molecule. As the gap increases, the reactivity of the compound decreases and vice versa. Optimization calculations have been used to derive FMOs energies and their plots are shown in Figure 3.

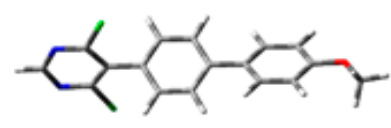

3a

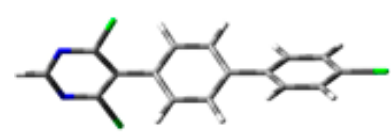

$3 d$

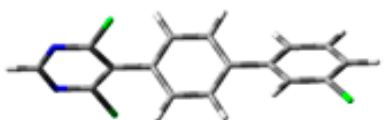

$3 \mathbf{g}$

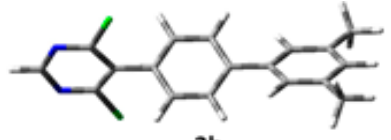

3b

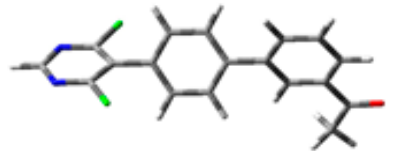

$3 e$

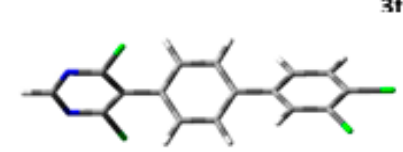

3h

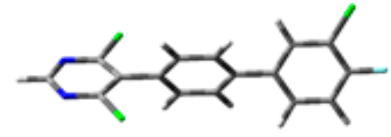

$3 c$

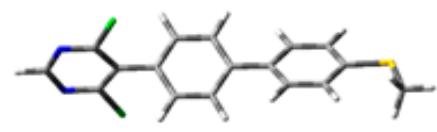

$3 \mathbf{f}$

Figure 2. Optimized structures of derivatives (3a-3h) at the PBE0-D3BJ/def2-TZVP/SMD water level of theory. In 3D models, gray color denotes carbon, white signifies hydrogen, red symbolizes oxygen, green represents chlorine, blue displays nitrogen and brown is for bromine atoms.
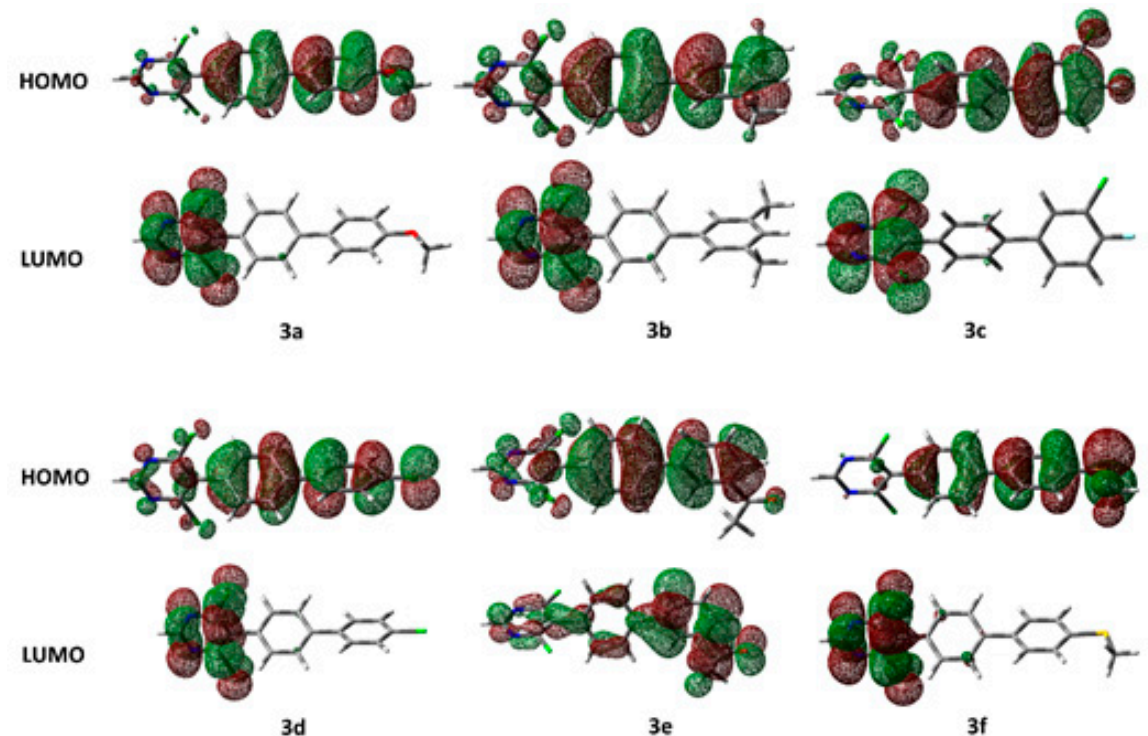

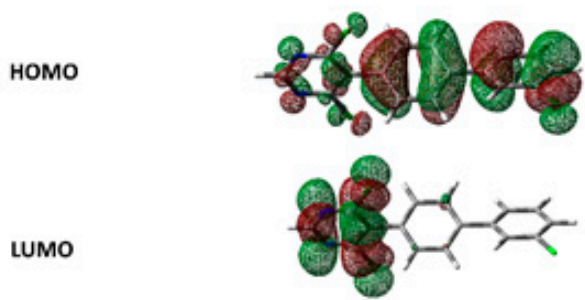

$3 g$

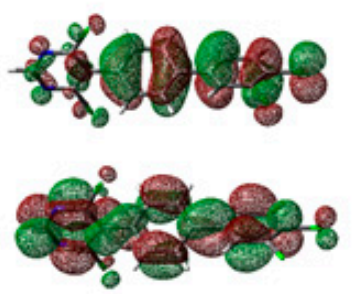

3h

Figure 3. A presentation of the frontier orbitals of the molecules (3a-3h) calculated at the PBE0-D3BJ/def2-TZVP/SMD water level of theory. 
Table 2 displays the HOMO-LUMO difference $(\Delta \mathrm{E})$ and hyperpolarizability $(\beta)$ values of compounds (3a-3h). The $\Delta \mathrm{E}$ values of the studied molecules lie in a relatively narrow range from 4.29 to $5.09 \mathrm{eV}$, representing that their reactivity is generally similar. The lowest $\Delta \mathrm{E}$ value belongs to that of compound 3f, i.e., $4.29 \mathrm{eV}$, suggesting it is the most reactive compound in the series. The $-\mathrm{SCH} 3$ group in the molecule can be considered to have an activating nature. Similarly, $3 \mathrm{~g}$ has the highest $\Delta \mathrm{E}$ value $(5.09 \mathrm{eV})$ which makes it the most stable compared to other compounds in the series. $3 \mathrm{c}$ is the other most stable compound which has deactivating groups $(\mathrm{Cl}$ and $\mathrm{F})$ on the aromatic rings.

Table 2. Energies of HOMO (Highest occupied molecular orbital), LUMO (Lowest unoccupied molecular orbital), the gap between HOMO and LUMO and hyperpolarizability $(\beta)$ values.

\begin{tabular}{ccccc}
\hline Compound & E $_{\text {HOMO }}$ & E LUMO $_{\text {LUO }}$ & $\begin{array}{c}\text { HOMO-LUMO } \\
\text { Gap }(\mathbf{e V})\end{array}$ & $\begin{array}{c}\text { Hyperpolarizability } \\
(\boldsymbol{\beta}) \text { (Hartrees) }\end{array}$ \\
\hline 3a & -6.13 & -1.59 & 4.53 & 6504.69 \\
3b & -6.51 & -1.60 & 4.91 & 2206.09 \\
3c & -6.62 & -1.61 & 5.01 & 2417.57 \\
3d & -6.54 & -1.61 & 4.94 & 2854.76 \\
3e & -6.69 & -1.81 & 4.88 & 1119.66 \\
3f & -5.89 & -1.60 & 4.29 & 8971.00 \\
3g & -6.70 & -1.61 & 5.09 & 1132.95 \\
3h & -6.64 & -1.65 & 4.99 & 2289.21 \\
\hline
\end{tabular}

The iso-density dispersion is looking very similar in these compounds. In the series of 5-([1,1'-biphenyl]-4-yl)-4,6-dichloropyrimidine, it is mostly present over all aromatic portions except for 4,6-dichloropyrimidine in the case of HOMO. In LUMO, it is generally found on the 4,6-dichloropyrimidine ring in all the compounds except $3 \mathbf{e}$ and $\mathbf{3 h}$. In compounds $\mathbf{3 e}$ and $\mathbf{3 h}$, it is distributed on the whole molecule.

The hyperpolarizability $(\beta)$ values of these compounds do not show them as very good non-linear optical (NLO) materials. Compound $3 \mathrm{f}$ has the highest $\beta$ value among all the compounds under study and the second highest value is shown by $3 \mathbf{a}$ which is due to $-\mathrm{SCH}_{3}$ and methoxy groups on the compounds, respectively. These groups are activating and electron-donating due to which they govern the electrons' push and pull mechanism in these molecules. These values are still not high enough to render these compounds as great NLO response materials.

\subsubsection{Molecular Electrostatic Potential}

Molecular electrostatic potential (MESP) maps are important 3D plots that help us to visualize the shape, size and charge distribution of compounds under study. These maps represent the density of electrons in different colors. As seen in the scale in Figure 4, the red color shows electron-rich sites of the molecule, while the blue side shows the low-electron density positions. Figure 4 represents MESP plots of compounds. With the help of these plots, the size of the molecule and its electron-rich and electron-deficient sites can be easily visualized that may be helpful in designing reactions of the molecules under study. 


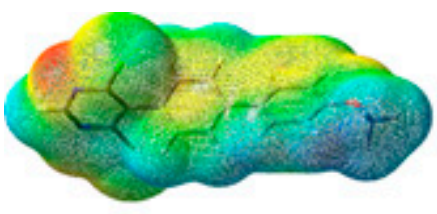

3a

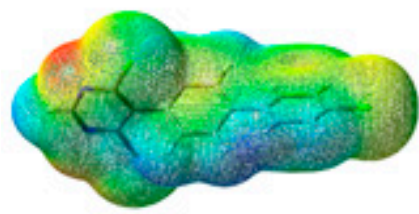

3d

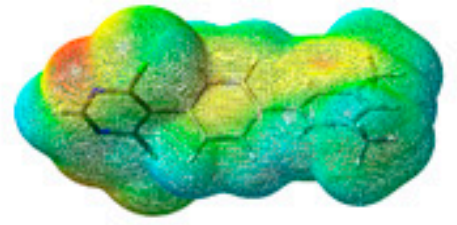

$3 b$

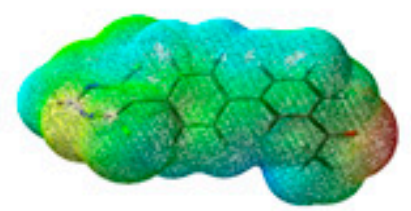

$3 e$

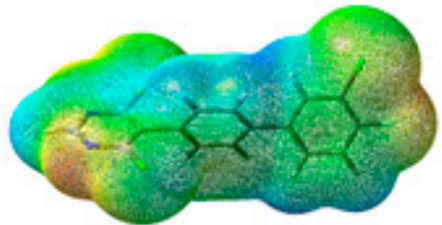

$3 c$

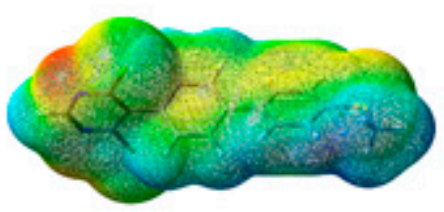

$3 f$

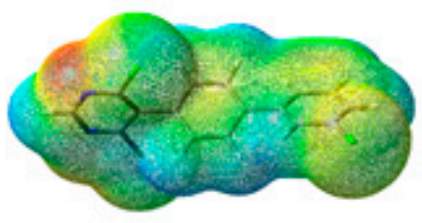

3g

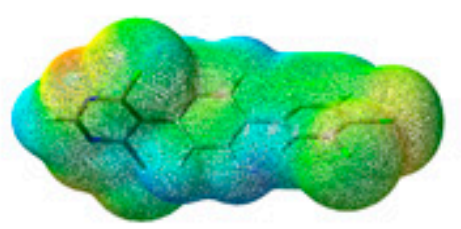

3h

$-5.563+2$

Figure 4. The presentation of molecular electrostatic potentials of the molecules (3a-3h) calculated at the PBE0-D3BJ/def2-TZVP/SMD water level of theory. The below scale represents the color coding. The values in the scale are in Hartrees.

\subsubsection{Conceptual DFT Reactivity Descriptors}

Chemical reactivity descriptors [56] like electron affinity (A), electronic chemical potential $(\mu)$, ionization potential (I) and chemical hardness $(\eta)$ are also derived from the FMO calculations. Reactivity descriptors' values of observed compounds are mentioned in Table 3. The value measurement of I and $\mathrm{A}$ has been calculated by Koopman's theorem and according to it, the negative of $\mathrm{E}_{\mathrm{HOMO}}-\mathrm{E}_{\mathrm{LUMO}}$ relates to the electron affinity (A) and ionization potential (I) of compounds $[57,58]$. Electrophilicity index $(\omega)$, chemical hardness $(\eta)$ and electronic chemical potential $(\mu)$ are then calculated from it as follows:

$$
\begin{gathered}
\eta=\left(E_{\text {HOMO }}-E_{\text {LUMO }}\right) / 2 \\
\mu=-\left(E_{\text {HOMO }}+E_{\text {LUMO }}\right) / 2 \\
\omega=\mu^{2} / 2 \eta
\end{gathered}
$$

Table 3. Reactivity descriptor's values of ionization potential (I), electron affinity (A), chemical hardness $(\eta)$, chemical potential $(\mu)$ and electrophilicity index $(\omega)$ of compounds (3a-3h).

\begin{tabular}{cccccc}
\hline Compound & $\begin{array}{c}\text { Ionization } \\
\text { Potential } \mathbf{I}(\mathbf{e V})\end{array}$ & $\begin{array}{c}\text { Electron } \\
\text { Affinity } \boldsymbol{A} \mathbf{( e V})\end{array}$ & $\begin{array}{c}\text { Chemical } \\
\text { Hardness } \boldsymbol{\eta} \mathbf{( e V})\end{array}$ & $\begin{array}{c}\text { Electronic Chemical } \\
\text { Potential }(\boldsymbol{\mu}) \mathbf{( e V )}\end{array}$ & $\begin{array}{c}\text { Electrophilicity } \\
\text { Index } \boldsymbol{\omega}(\mathbf{e V})\end{array}$ \\
\hline 3a & 6.13 & 1.59 & -2.27 & 3.86 & -3.29 \\
3b & 6.51 & 1.60 & -2.46 & 4.06 & -3.35 \\
3c & 6.62 & 1.61 & -2.51 & 4.12 & -3.38 \\
3d & 6.54 & 1.61 & -2.47 & 4.08 & -3.36 \\
3e & 6.69 & 1.81 & -2.44 & 4.25 & -3.70 \\
3f & 5.89 & 1.60 & -2.15 & 3.74 & -3.27 \\
3g & 6.70 & 1.61 & -2.54 & 4.16 & -3.39 \\
3h & 6.64 & 1.65 & -2.50 & 4.15 & -3.44 \\
\hline
\end{tabular}


The lowest values of electron affinity and ionization energy of compound $\mathbf{3 f}$ suggest its reactivity is also estimated by FMO analysis and thus can be co-linked. This supports the greater predicted reactivity of $\mathbf{3 f}$ in the series. It is clearly related to the fact that a higher energy of HOMO is related to a greater reactivity of the molecules in electrophilic reactions and vi. Compound $3 \mathrm{f}$ has the highest HOMO energy as evident from Table 2. Similarly, the chemical hardness $(\eta)$ of the molecule is directly related to the HOMO-LUMO energy gap. A larger gap would mean a harder molecule and vice versa. This also supports the findings of the FMO analysis, thus predicting compounds $3 \mathrm{~g}$ and $\mathbf{3 c}$ to be the most stable molecules in the chemical reaction as compared to the others under study.

\section{Conclusions}

The ability of 5-([1,1'-biphenyl]-4-yl)-4,6-dichloropyrimidine for Suzuki coupling was described. The examples reported in the literature indicate pyrimidine is an excellent substrate for the coupling reaction, while the above-mentioned phenyl-substituted pyrimidine proved to deviate from this trend. It was concluded that yields of newly synthesized compounds might be affected by nitrogen atoms of pyrimidine and electron-withdrawing boronic acids, whereas good to better yields were obtained with the use of electron-rich boronic acid and 5-(4-bromophenyl)-4,6-dichloropyrimidine (1) with a suitable solvent, base and $\mathrm{Pd}\left(\mathrm{PPh}_{3}\right)_{4}$. DFT calculations have been calculated on newly prepared products to know about their electronic and structural properties. Exploration of frontier orbitals and reactivity descriptors, i.e., electron affinity, ionization potential, electrophilicity index, electronic chemical potential and chemical hardness, exposed that the compound $\mathbf{3 g}$ is the most stable, while $\mathbf{3 f}$ is the most reactive in the whole series.

Author Contributions: Conceptualization, A.M. and N.R.; methodology, A.M. and I.K.; investigation, A.M., I.K. and G.A.; resources, N.R. and M.A.H.; writing — original draft preparation, A.M., I.K., and M.A.H.; writing-review and editing, N.R., G.A., A.F.Z. and A.A.A.; funding acquisition, N.R., S.A.A.S., Z.A.Z. and S.S. analyzed the data and wrote the original draft, helped in experiments and contributed reagents/material and analysis tools. All authors have read and agreed to the published version of the manuscript.

Funding: This research received no external funding.

Acknowledgments: The authors would like to acknowledge the Ministry of Higher Education (MOHE) Malaysia for financial support under the Fundamental Research Grant Scheme (FRGS) with sponsorship reference numbers FRGS/1/2019/STG05/UITM/02/9. The authors would also like to acknowledge Universiti Teknologi MARA for the financial support under the reference number 600-IRMI/FRGS 5/3 (424/2019). The data present here are part of a Ph.D. Thesis. The authors gratefully acknowledge the financial support by Higher Education Commission (HEC), Pakistan, through indigenous scholarship for Ayesha Malik PIN: 2PS5-056.

Conflicts of Interest: The authors declare no conflict of interest.

\section{References}

1. Naik, T.; Chikhalia, K. Studies on synthesis of pyrimidine derivatives and their pharmacological evaluation. J. Chem. 2007, 4, 60-66. [CrossRef]

2. Rodrigues, A.L.; Rosa, J.M.; Gadotti, V.M.; Goulart, E.C.; Santos, M.M.; Silva, A.V.; Sehnem, B.; Rosa, L.S.; Goncalves, R.M.; Correa, R.; et al. Antidepressant-like and antinociceptive-like actions of 4-(4'-chlorophenyl)-6-(4"-methylphenyl)-2-hydrazinepyrimidine Mannich base in mice. Pharmacol. Biochem. Behav. 2005, 82, 156-162. [CrossRef] [PubMed]

3. Xie, F.; Zhao, H.; Zhao, L.; Lou, L.; Hu, Y. Synthesis and biological evaluation of novel 2,4,5-substituted pyrimidine derivatives for anticancer activity. Bioorg. Med. Chem. Lett. 2009, 19, 275-278. [CrossRef] [PubMed]

4. Bhalgat, C.M.; Irfan Ali, M.; Ramesh, B.; Ramu, G. Novel pyrimidine and its triazole fused derivatives: Synthesis and investigation of antioxidant and anti-inflammatory activity. Arab. J. Chem. 2014, 7, $986-993$. [CrossRef]

5. Anupama, B.; Dinda, S.C.; Prasad, Y.R.; Rao, A.V. Synthesis and antimicrobial activity of some new 2, 4,6-trisubstituted pyrimidines. Int. J. Res. Pharm. Chem. 2012, 2, 231-236. 
6. Slusarczyk, M.; Serpi, M.; Pertusati, F. Phosphoramidates and phosphonamidates (ProTides) with antiviral activity. Antivir. Chem. Chemother. 2018, 26, 1-31. [CrossRef] [PubMed]

7. Abdelgawad, M.A.; Bakr, R.B.; Azouz, A.A. Novel pyrimidine-pyridine hybrids: Synthesis, cyclooxygenase inhibition, anti-inflammatory activity and ulcerogenic liability. Bioorganic Chem. 2018, 77, 339-348. [CrossRef]

8. Ashour, H.M.; Shaaban, O.G.; Rizk, O.H.; El-Ashmawy, I.M. Synthesis and biological evaluation of thieno $\left[2^{\prime}, 3^{\prime}: 4,5\right]$ pyrimido[1,2-b][1,2,4]triazines and thieno[2,3-d][1,2,4]triazolo[1,5-a]pyrimidines as anti-inflammatory and analgesic agents. Eur. J. Med. Chem. 2013, 62,341-351. [CrossRef]

9. Kumar, D.; Khan, S.I.; Tekwani, B.L.; Ponnan, P.; Rawat, D.S. 4-Aminoquinoline-pyrimidine hybrids: Synthesis, antimalarial activity, heme binding and docking studies. Eur. J. Med. Chem. 2015, 89, 490-502. [CrossRef]

10. Kappe, C.O. 100 years of the biginelli dihydropyrimidine synthesis. Tetrahedron 1993, 49, 6937-6963. [CrossRef]

11. Lee, H.W.; Kim, B.Y.; Ahn, J.B.; Kang, S.K.; Lee, J.H.; Shin, J.S.; Ahn, S.K.; Lee, S.J.; Yoon, S.S. Molecular design, synthesis, and hypoglycemic and hypolipidemic activities of novel pyrimidine derivatives having thiazolidinedione. Eur. J. Med. Chem. 2005, 40, 862-874. [CrossRef]

12. Sharma, V.; Chitranshi, N.; Agarwal, A.K. Significance and biological importance of pyrimidine in the microbial world. Int. J. Med. Chem. 2014, 2014,1-31. [CrossRef]

13. Schomaker, J.M.; Delia, T.J. Arylation of halogenated pyrimidines via a Suzuki coupling reaction. J. Org. Chem. 2001, 66, 7125-7128. [CrossRef]

14. Majumdar, K.; Sinha, B.; Maji, P.; Chattopadhyay, S. Palladium-catalyzed intramolecular arylation of pyrimidines: A novel and expedient avenue to benzannulated pyridopyrimidines. Tetrahedron 2009, 65, 2751-2756. [CrossRef]

15. Khalafi-Nezhad, A.; Zare, A.; Parhami, A.; Soltani Rad, M.N.; Nejabat, G.R. Regioselective N-Arylation of Some Pyrimidine and Purine Nucleobases. Synth. Commun. 2006, 36, 3549-3562. [CrossRef]

16. Haas, D.; Hammann, J.M.; Greiner, R.; Knochel, P. Recent Developments in Negishi Cross-Coupling Reactions. ACS Catal. 2016, 6, 1540-1552. [CrossRef]

17. Kanwal, I.; Mujahid, A.; Rasool, N.; Rizwan, K.; Malik, A.; Ahmad, G.; Shah, S.A.A.; Rashid, U.; Nasir, N.M. Palladium and Copper Catalyzed Sonogashira cross Coupling an Excellent Methodology for CC Bond Formation over 17 Years: A Review. Catalysts 2020, 10, 443. [CrossRef]

18. Imran, H.M.; Rasool, N.; Kanwal, I.; Hashmi, M.A.; Altaf, A.A.; Ahmed, G.; Malik, A.; Kausar, S.; Khan, S.U.D.; Ahmad, A. Synthesis of halogenated [1, 1'-biphenyl]-4-yl benzoate and [1, 1': 3', 1'"-terphenyl]-4'-yl benzoate by palladium catalyzed cascade $\mathrm{C}-\mathrm{C}$ coupling and structural analysis through computational approach. J. Mol. Struct. 2020, 1222, 128839-128848. [CrossRef]

19. Noreen, M.; Rasool, N.; Gull, Y.; Nasim, F.U.H.; Zahoor, A.F.; Yaqoob, A.; Kousar, S.; Zubair, M.; Bukhari, I.H.; Rana, U.A. A facile synthesis of new 5-aryl-thiophenes bearing sulfonamide moiety via Pd(0)-catalyzed Suzuki-Miyaura cross coupling reactions and 5-bromothiophene-2-acetamide: As potent urease inhibitor, antibacterial agent and hemolytically active compounds. J. Saudi Chem. Soc. 2017, 21, S403-S414. [CrossRef]

20. Sial, N.; Rasool, N.; Rizwan, K.; Altaf, A.A.; Ali, S.; Malik, A.; Zubair, M.; Akhtar, A.; Kausar, S.; Shah, S.A.A. Efficient synthesis of 2,3-diarylbenzo [b] thiophene molecules through palladium (0) Suzuki-Miyaura cross-coupling reaction and their antithrombolyitc, biofilm inhibition, hemolytic potential and molecular docking studies. Med. Chem. Res. 2020, 29, 1486-1496. [CrossRef]

21. Rizwan, K.; Rasool, N.; Rehman, R.; Mahmood, T.; Ayub, K.; Rasheed, T.; Ahmad, G.; Malik, A.; Khan, S.A.; Akhtar, M.N. Facile synthesis of N-(4-bromophenyl)-1-(3-bromothiophen-2-yl) methanimine derivatives via Suzuki cross-coupling reaction: Their characterization and DFT studies. Chem. Cent. J. 2018, 12, 84-93. [CrossRef]

22. Chen, Z.; Vorobyeva, E.; Mitchell, S.; Fako, E.; Ortuño, M.A.; López, N.; Collins, S.M.; Midgley, P.A.; Richard, S.; Vilé, G. A heterogeneous single-atom palladium catalyst surpassing homogeneous systems for Suzuki coupling. Nat. Nanotechnol. 2018, 13, 702-707. [CrossRef] [PubMed]

23. Walker, S.D.; Barder, T.E.; Martinelli, J.R.; Buchwald, S.L. A rationally designed universal catalyst for Suzuki-Miyaura coupling processes. Angew. Chem. 2004, 116, 1907-1912. [CrossRef]

24. Li, W.; Nelson, D.P.; Jensen, M.S.; Hoerrner, R.S.; Javadi, G.J.; Cai, D.; Larsen, R.D. Palladium-Catalyzed Regioselective Arylation of Imidazo[1,2-a]pyrimidine. Org. Lett. 2003, 5, 4835-4837. [CrossRef] 
25. Jiang, H.; Bellomo, A.; Zhang, M.; Carroll, P.J.; Manor, B.C.; Jia, T.; Walsh, P.J. Palladium-Catalyzed direct $\mathrm{C}-\mathrm{H}$ arylation of 3-(methylsulfinyl) thiophenes. Org. Lett. 2018, 20, 2522-2525. [CrossRef]

26. Fernandes, S.S.; Aires-de-Sousa, J.; Belsley, M.; Raposo, M.M.M. Synthesis of pyridazine derivatives by Suzuki-Miyaura cross-coupling reaction and evaluation of their optical and electronic properties through experimental and theoretical studies. Molecules 2018, 23, 3014. [CrossRef]

27. Farooq, H.; Rasool, N.; Ansari, M.T.; Rizwan, K.; Iqbal, S.; Mahmood, T.; Israr, H.; Ayub, K.; Rasheed, T.; Zareen, S. Selective arylation of phenol protected propargyl bromide via Pd-catalysed suzuki coupling reaction: Synthesis, mechanistic studies by DFT calculations and their pharmacological aspects. Acta Pol. Pharm. 2018, 75, 911-919.

28. Ahmad, G.; Rasool, N.; Ikram, H.M.; Gul Khan, S.; Mahmood, T.; Ayub, K.; Zubair, M.; Al-Zahrani, E.; Ali Rana, U.; Akhtar, M.N. Efficient synthesis of novel pyridine-based derivatives via Suzuki cross-coupling reaction of commercially available 5-bromo-2-methylpyridin-3-amine: Quantum mechanical investigations and biological activities. Molecules 2017, 22, 190. [CrossRef]

29. Frisch, M.J.; Trucks, G.W.; Schlegel, H.B.; Scuseria, G.E.; Robb, M.A.; Cheeseman, J.R.; Scalmani, G.; Barone, V.; Mennucci, B.; Petersson, G.A.; et al. Gaussian 09 Revision D. 01; Gaussian Inc.: Wallingford, CT, USA, 2010.

30. Perdew, J.P.; Burke, K.; Ernzerhof, M. Generalized Gradient Approximation Made Simple. Phys. Rev. Lett. 1997, 77, 3865-3868, reprinted in Phys. Rev. Lett. 1997, 78, 1396-1396. [CrossRef]

31. Adamo, C.; Barone, V. Toward reliable density functional methods without adjustable parameters: The PBE0 model. J. Chem. Phys. 1999, 110, 6158-6170. [CrossRef]

32. Weigend, F.; Ahlrichs, R. Balanced basis sets of split valence, triple zeta valence and quadruple zeta valence quality for H to Rn: Design and assessment of accuracy. Phys. Chem. Chem. Phys. 2005, 7, 3297-3305. [CrossRef] [PubMed]

33. Grimme, S. Semiempirical GGA-type density functional constructed with a long-range dispersion correction. J. Comput. Chem. 2006, 27, 1787-1799. [CrossRef] [PubMed]

34. Grimme, S.; Antony, J.; Ehrlich, S.; Krieg, H. A consistent and accurate ab initio parametrization of density functional dispersion correction (DFT-D) for the 94 elements H-Pu. J. Chem. Phys. 2010, 132, 154104-154123. [CrossRef] [PubMed]

35. Grimme, S.; Ehrlich, S.; Goerigk, L. Effect of the damping function in dispersion corrected density functional theory. J. Comput. Chem. 2011, 32, 1456-1465. [CrossRef]

36. Cammi, R.; Mennucci, B.; Tomasi, J. Fast Evaluation of Geometries and Properties of Excited Molecules in Solution: A Tamm-Dancoff Model with Application to 4-Dimethylaminobenzonitrile. J. Phys. Chem. A 2000, 104, 5631-5637. [CrossRef]

37. Cossi, M.; Barone, V. Solvent effect on vertical electronic transitions by the polarizable continuum model. J. Chem. Phys. 2000, 112, 2427-2435. [CrossRef]

38. Cossi, M.; Barone, V. Time-dependent density functional theory for molecules in liquid solutions. J. Chem. Phys. 2001, 115, 4708-4717. [CrossRef]

39. Cossi, M.; Rega, N.; Scalmani, G.; Barone, V. Polarizable dielectric model of solvation with inclusion of charge penetration effects. J. Chem. Phys. 2001, 114, 5691-5701. [CrossRef]

40. Cossi, M.; Scalmani, G.; Rega, N.; Barone, V. New developments in the polarizable continuum model for quantum mechanical and classical calculations on molecules in solution. J. Chem. Phys. 2002, 117, 43-54. [CrossRef]

41. Cossi, M.; Rega, N.; Scalmani, G.; Barone, V. Energies, structures, and electronic properties of molecules in solution with the C-PCM solvation model. J. Comput. Chem. 2003, 24, 669-681. [CrossRef]

42. Tomasi, J.; Mennucci, B.; Cammi, R. Quantum mechanical continuum solvation models. Chem. Rev. 2005, 105, 2999-3093. [CrossRef] [PubMed]

43. Marenich, A.V.; Cramer, C.J.; Truhlar, D.G. Universal Solvation Model Based on Solute Electron Density and on a Continuum Model of the Solvent Defined by the Bulk Dielectric Constant and Atomic Surface Tensions. J. Phys. Chem. B 2009, 113, 6378-6396. [CrossRef]

44. CYLview; Legault, C.Y. Université de Sherbrooke. Available online: http://www.cylview.org (accessed on 5 July 2020).

45. Lee, D.H.; Choi, M.; Yu, B.W.; Ryoo, R.; Taher, A.; Hossain, S.; Jin, M.J. Expanded Heterogeneous Suzuki-Miyaura Coupling Reactions of Aryl and Heteroaryl Chlorides under Mild Conditions. Adv. Synth. 2009, 351, 2912-2920. [CrossRef] 
46. Riyadh, S.M.; Farghaly, T.A.; Abdallah, M.A.; Abdalla, M.M.; El-Aziz, M.R.A. New pyrazoles incorporating pyrazolylpyrazole moiety: Synthesis, anti-HCV and antitumor activity. Eur. J. Med. Chem. 2010, 45, 1042-1050. [CrossRef] [PubMed]

47. Itoh, T.; Mase, T. Direct synthesis of hetero-biaryl compounds containing an unprotected NH2 group via Suzuki-Miyaura reaction. Tetrahedron Lett. 2005, 46, 3573-3577. [CrossRef]

48. Ahmad, G.; Rasool, N.; Rizwan, K.; Altaf, A.A.; Rashid, U.; Mahmood, T.; Ayub, K. Role of Pyridine Nitrogen in Palladium-Catalyzed Imine Hydrolysis: A Case Study of (E)-1-(3-bromothiophen-2-yl)N-(4-methylpyridin-2-yl)methanimine. Molecules 2019, 24, 2609. [CrossRef] [PubMed]

49. Li, Z.; Gelbaum, C.; Campbell, Z.S.; Gould, P.C.; Fisk, J.S.; Holden, B.; Jaganathan, A.; Whiteker, G.T.; Pollet, P.; Liotta, C.L. Pd-Catalyzed Suzuki coupling reactions of aryl halides containing basic nitrogen centers with arylboronic acids in water in the absence of added base. New J. Chem. 2017, 41, 15420-15432. [CrossRef]

50. Wang, K.; Fu, Q.; Zhou, R.; Zheng, X.; Fu, H.; Chen, H.; Li, R. Tetraphosphine/palladium-catalyzed Suzuki-Miyaura coupling of heteroaryl halides with 3-pyridine- and 3-thiopheneboronic acid: An efficient catalyst for the formation of biheteroaryls. Appl. Organomet. Chem. 2013, 27, 232-238. [CrossRef]

51. Kuivila, H.G.; Nahabedian, K.V. Electrophilic Displacement Reactions. X. General Acid Catalysis in the Protodeboronation of Areneboronic Acids1-3. J. Am. Chem. Soc. 1961, 83, 2159-2163. [CrossRef]

52. Nitulescu, G.M.; Draghici, C.; Olaru, O.T.; Matei, L.; Ioana, A.; Dragu, L.D.; Bleotu, C. Synthesis and apoptotic activity of new pyrazole derivatives in cancer cell lines. Bioorganic Med. Chem. 2015, 23, 5799-5808. [CrossRef]

53. Kuivila, H.G.; Reuwer, J.F.; Mangravite, J.A. Electrophilic Displacement Reactions. XVI. Metal Ion Catalysis in the Protodeboronation of Areneboronic Acids1-3. J. Am. Chem. Soc. 1964, 86, 2666-2670. [CrossRef]

54. Cox, P.A.; Reid, M.; Leach, A.G.; Campbell, A.D.; King, E.J.; Lloyd-Jones, G.C. Base-Catalyzed Aryl-B(OH $)_{2}$ Protodeboronation Revisited: From Concerted Proton Transfer to Liberation of a Transient Aryl Anion. J. Am. Chem. Soc. 2017, 139, 13156-13165. [CrossRef] [PubMed]

55. Arshad, M.N.; Bibi, A.; Mahmood, T.; Asiri, A.M.; Ayub, K. Synthesis, crystal structures and spectroscopic properties of triazine-based hydrazone derivatives; a comparative experimental-theoretical study. Molecules 2015, 20, 5851-5874. [CrossRef] [PubMed]

56. Sumrra, S.H.; Kausar, S.; Raza, M.A.; Zubair, M.; Zafar, M.N.; Nadeem, M.A.; Mughal, E.U.; Chohan, Z.H.; Mushtaq, F.; Rashid, U. Metal based triazole compounds: Their synthesis, computational, antioxidant, enzyme inhibition and antimicrobial properties. J. Mol. Struct. 2018, 1168, 202-211. [CrossRef]

57. Nayak, P.K.; Periasamy, N. Calculation of electron affinity, ionization potential, transport gap, optical band gap and exciton binding energy of organic solids using 'solvation' model and DFT. Org. Electron. 2009, 10, 1396-1400. [CrossRef]

58. Zhan, C.G.; Nichols, J.A.; Dixon, D.A. Ionization Potential, Electron Affinity, Electronegativity, Hardness, and Electron Excitation Energy: Molecular Properties from Density Functional Theory Orbital Energies. J. Phys. Chem. A 2003, 107, 4184-4195. [CrossRef]

Publisher's Note: MDPI stays neutral with regard to jurisdictional claims in published maps and institutional affiliations.

(C) 2020 by the authors. Licensee MDPI, Basel, Switzerland. This article is an open access article distributed under the terms and conditions of the Creative Commons Attribution (CC BY) license (http://creativecommons.org/licenses/by/4.0/). 